\title{
Value Added: Best Practices For The Utilization Of Assistant Principals' Skills And Knowledge In Schools
}

Ann T. Hilliard, Ed.D., Bowie State University, USA

Sandra S. Newsome, Ed.D., Bowie State University, USA

\begin{abstract}
There are many demands on schools today to perform at a high level with competence that improves teaching and learning and promotes higher student achievement. When students perform below national standards, schools may be given a "no vote of confidence" from the public. Therefore, principals in schools need to find ways to groom and utilize the talents of assistant principals in a broader capacity. The assistant principal is the individual who should work closely with the principal to handle management and instructional matters within the school. Too many school districts today have principals who continue to under utilize the strong talents, skills, knowledge of the assistant principal (Bolman \& Terrence, 2002). Typical uses of an assistant principal in too many schools include being on hall, bus, recess, and cafeteria duty and handling of student discipline on a daily basis. Some assistant principals bring to the school setting skills and knowledge related to broader practices for improving instruction and management in schools. In order to help create and maintain effective schools, there should be identified ways to improve the use of assistant principals' skills and knowledge that could impact teaching and learning. A central part of being a great school leader is to cultivate the leadership skills of others, especially the assistant principal (Darling-Hammond, 2007).

The purpose of this study is to discuss the contemporary role of today's assistant principals including getting to know the assistant principal, value in shared leadership, developing the assistant principal's leadership skills, use of technology, and the professional learning community. The benefits of this study hopefully will remind principals and school leaders to assess the skills and knowledge that the assistant principal brings to the school setting and to utilize those talents for improving school performance. The effective principal will also continue to provide opportunities for leadership development and engagement for the assistant principal in meaningful ways that support strong instructional leadership.
\end{abstract}

Keywords: Assistant Principal; Leadership Skills; Best Practices; Professional Learning Communities

\section{INTRODUCTION}

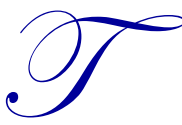

he principal of the school should realize the talents of all faculty members, staff and the assistant principal. A principal cannot have too many effective supporting staff in the building; therefore, the wisdom, ability and knowledge to see the strength in support staff is essential. No longer should assistant principals only act as disciplinarian facilitators, hall and bus monitors, cafeteria duty individuals and conflict coordinators, but being at the school to serve in a broader capacity as an instructional leader. The assistant principal should be encouraged by the principal to serve as an instructional leader, financial manager and public relations person. The principal should see the assistant principal as an individual who can fully operate the school during the absence of the principal. The principal should provide professional development training for the assistant principal in areas needing strengthening, because it is hoped that the assistant principal will soon assume the role as principal in a school. Based on data, a high percent of principals are near or at retirement age across the nation and a 
pool of qualified, certified and experienced assistant principals must be ready to take the position as a principal. According to NASSP, within the next decade it is estimated that there will be at least a 40 percent shortage of school principals in American Schools. The replacement of school leaders should be qualified, certified and experienced in order to effectively take the place of retiring principals. The lack of qualified principals can affect the quality of schools performance. Therefore, more assistant principals should be trained and groomed for the position of principalship (NASSP, 2000).

\section{GET TO KNOW THE ASSISTANT PRINCIPAL}

The principal needs to revisit the assistant principal's resume and have a courageous conversation with the assistant principal. In the conversation, the principal should try to learn more about the strengths and aspirations of the assistant principal. If examined carefully, the principal may be surprised to learn about the talents that many assistant principals may bring to the school environment. Some of the talents may include being experienced instructional leaders, technologically savvy, excellent community relations individuals and being resourceful in securing educational partners to support school programs. The principal must realize that all individuals in the school are important who serve students and getting to know the talents of staff and teachers could be an added value to the environment of the school (Bartholomew \& Fusarelli, 2003).

In further conversations with the assistant principal, the principal could emphasize the need for rigor and relevance especially being connected to having a stronger curriculum and instructional program in the school. The intentional use of data too, should drive decision-making for improving the opportunities for students to see where they are now and where they need to go in order to improve their academic performance.

In a progressive and professional manner, the assistant principal should have the opportunity to share with the principal views about increasing the assistant principal's leadership capacity and to take on an active role in articulating the living school improvement plan. Volunteering to coordinate or facilitate team meetings and grade level meetings is a positive practice for the assistant principal. Staying literate about effective outcomes for improving schools based on research is information that the assistant principal should learn and share with the principal and teachers. As a strong instructional leader, the assistant principal should conduct group demonstration lessons and to take the time to teach classes during the academic year. With the support of the principal, the assistant principal can and should be able to develop those instructional leadership skills and knowledge that can lead to a more productive and high performing school (Lashway, 2002).

\section{VALUE IN SHARED LEADERSHIP}

Principals should position themselves as being comfortable as transformational and distributive leaders by sharing instructional leadership, supervision and management leadership opportunities with assistant principals in the school. The greatest source in leadership is in the collaboration of sharing ideas (Sergiovanni, 1994). Great leaders will teach leadership skills to their assistant principals and teacher leaders, who will then help do the "heavy lifting" of moving the school from where it is today to where it needs to be in the future (McBean, 2013). The principal needs to know the talents, skills and knowledge that the assistant principal processes and to utilize those skills and knowledge in a meaningful manner to help improve the quality of the school. The impact on student learning is influenced by the quality of the leadership and the teachers within the school (Waters, Marzano \& McNulty, 2006). The assistant principal should not be overlooked or ignored, because the assistant principal is a valuable resource in the school. Just to name a few, the assistant principal with appropriate knowledge and skills would be able to help the school by:

1. Establishing learning communities for teachers with a focus on student learning.

2. Demonstrating skills and knowledge of being a strong instructional leader.

3. Expanding resources and partnership support to the school.

4. Coaching teachers and encouraging teachers to be leaders by building teachers' knowledge, skills and professional disposition and practices to lead to improve the school, because this practice too will help teachers believe that they are valued and supported.

5. Developing students as leaders in the school i.e. tutors and peer mentors.

154 Copyright by author(s) $\underline{\text { Creative Commons License CC-BY }}$

2013 The Clute Institute 
Being a valuable resource for the school, the assistant principal could assist the principal in helping teachers to do a better job in teaching and learning, setting a positive tone for the school, and improving the academic growth of students. Helping teachers to improve their craft will help teachers to believe that the school leadership team cares and value them as lifelong learners (Aspin \& Chapman, 2007).

\section{DEVELOPING THE ASSISTANT PRINCIPAL}

The research is growing more today regarding the assistant principal's crucial role in schools and how too many assistant principals are under-utilized in schools. Therefore, in order to decrease this perceived perception the principal should:

1. Encourage the assistant principal to attend Board of Education meetings monthly to stay "informed" and to "network" with other school leaders in different settings.

2. Encourage the assistant principal to attend local, state and national conferences that promote reading, math and science improvement programs in schools and present a global view of teaching and learning.

3. Encourage the assistant principal to participate in action research projects with others and to publish the experiences in refereed journals.

4. Encourage the assistant principal to participate in the writing of policy related issues.

5. Encourage the assistant principal to present workshops and participate in collaborative planning monthly meetings and professional development activities that improves instruction, student learning and building management.

6. Encourage the assistant principal to enroll in a formal leadership development training program or institute in preparation for the principalship.

The quality in the development of assistant principals is possible when preparation programs or institutes provide the integration of program coursework and clinical field work that are in alignment with priorities of the school district and based on leadership national standards (Elmore, 2000).

\section{PROMOTING THE USE OF TECHNOLOGY}

The assistant principal as an instructional leader could use technology as a tool in and out of the classroom. In the classroom, the assistant principal could use technology applications in real-time to observe a lesson and record the lesson and to share the observation with the teacher. During the teacher's planning time or at the end of the day the assistant principal should cite positive points observed in the teacher's classroom and how the teacher may strengthen some aspects of the lesson. The technology could be used to pug in to conduct professional staff development, emails, electronic handouts and sharing other resources with teachers. Using convenient technology devices, the assistant principal "on the go" could send and receive emails, texts, videos and telephone messages related to the job. The assistant principal may find the needed resources to ensure that all teachers have access to technology devices to capture field trip information and other information to enhance the instructional delivery process (Rainie, 2012). The assistant principal could work with teachers, if needed, to ensure that teachers know how to use available technology in the classroom.

\section{PROFESSIONAL LEARNING COMMUNITY}

The assistant principal could establish a professional learning community for the school for the purpose of bringing teachers and others together to share ideas and best practices with a focus on student learning. Basically, the goal of the professional learning community is to collaborate on critical issues that impact student learning. The professional learning community should be organized to address goals of the school and share successful instructional strategies that are supported by data and research. The professional learning community after reviewing data should be able to identify students' needs and provide appropriate instruction and interventions to improve the performance of students (Ferlesso, 2009). It may be learned too that instructional services need to be delivered by different methods because students have different living styles. Some common goals of typical learning communities are as follow: 
1. Establish collaborative teams who work together to compose assessments that are aligned with state standards.

2. Seek measurable ways to improve instructional services to meet the needs of all students by using data driven decision making and to determine best practices to ensure that all students are learning to their highest potential.

3. Provide opportunities to ensure that students are successful based on curriculum expectations and to observe students' performance weekly to see how well students are mastering the required skills.

The learning community adds so much value to a school's environment, because it is a physical presence that is there to continue to engage teachers and staff working collaboratively toward to improve the performance of students. The learning community creates trust among teachers and staff to work together to solve academic, social and cultural concerns within the environment of the school. In order to make improvements in the school environment, members of the learning community must identify collaboratively issues or concerns within the school and work toward a possible solution to solving problems (Fullan \& Miles, 2005). When individuals learn together, individuals may become motivated from the experience. When teachers feel that they are supported in improving the skills and knowledge of students, teachers feel more productive in their work (Little, 1997). There is a dimensional scale of learning for teachers and staff when the learning community shares leadership practices, vision and value. The learning community is a place where collaborative learning takes place for the team, and where continuous support from team members is evident. Members of the learning community team are willing to share their personal practices for improving instruction. For participants in the professional learning community, the work environment builds confidence and creates a culture that is caring and nurturing (Hord, 1997). An example of the conceptual framework below communicates to readers the common areas that are addressed by a typical learning community in a school environment as illustrated in Figure 1.

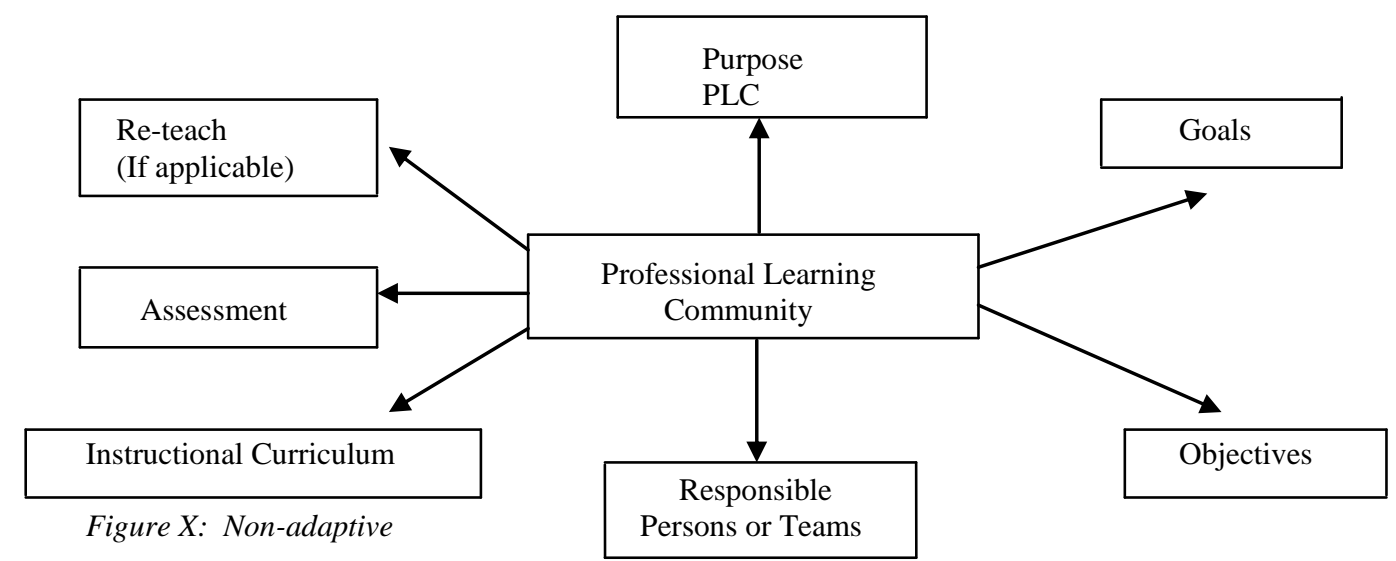

Figure 1: Conceptual Framework of a Professional Learning Community

The professional learning community has proven to be worthwhile according to DuFour. The professional learning community works collaboratively in a consistent manner to review data and share best practices for the major purpose of meeting the specific needs of students through improved instructional delivery services (Hattie, 2012). Professional learning communities are committed to the success of all students that they serve. In essence, the professional learning community takes on the responsibility that members of the community are responsible for student learning. Students should be taught in an effective manner with relevant information, because students need to be prepared for the global marketplace. The professional learning community members participate in collective teaching and learning, share leadership, values, school's vision and support the goals and objectives of the professional learning community (DuFour, 2004). 


\section{CONCLUSION}

The great demands on schools today force principals to think about utilizing a team approach for school improvement. This is why principals need to know how to value the knowledge and skills of the assistant principal. Principals need to know and assess the knowledge and skills that assistant principals bring to the table of leadership. Also, the principal needs to find ways to embrace these attributes that assistant principals have for school improvement. Principals need to share or distribute the leadership responsibility to the local school building team with trust and support to the assistant principal as the facilitator of the team. Principals need to build on the expertise of assistant principals as an asset to the school by ensuring that the assistant principal be exposed to excellent practical training as a school leader for upward mobility to become a principal. The principal should provide opportunities for the assistant principal to participate in professional development opportunities in leadership preparedness programs. The principal should make it a point to engage the assistant principal in collecting and analyzing data in a comprehensive manner that is relevant to improving instruction. Competence in financial management matters is also important to the success of a school leader. Therefore, the assistant principal should be exposed to handling school financial matters accurately through the leadership and support of the principal. In order to market the school in a positive light, the assistant principal should also serve as an effective public relations individual for the school (Bloom \& Krovetz, 2001). The value added in any school environment, again, is to utilize the positive leadership skills and knowledge that the assistant principal has for school improvement.

\section{AUTHOR INFORMATION}

Dr. Ann Toler Hilliard is an assistant professor who teaches in the Department of Educational Studies and Leadership at Bowie State University, U.S.A. The author teaches courses related to educational leadership, policy issues, planning and evaluating, human resources, and dissertation one/two; group dynamics and human relations. The author's research focus is instructional leadership, learning communities, professional development, teaching and learning, blended learning and international studies. The author coordinates activities that provide professional experiences for graduate candidates who are seeking the opportunity to serve as school administrators at the building and district level. Education: Ed.D. George Washington University, M.S. Johns Hopkins University, M.A.T. Trinity University-Washington, B.S. Elizabeth City State University and Certificate for Consulting, Harvard University. E-mail: draph1@juno.com (Corresponding author)

Dr. Sandra Singleton Newsome is an adjunct professor who teaches in the Department of Teaching and Learning and Professional Development at Bowie State University, U.S.A. The author teaches reading, counseling and general psychology courses. She supervises student teachers and serves as a supervising mentor and administrator to candidates seeking the master's degree in school administration at Trinity University - Washington. The author's research interest is teaching and learning and administration. Education: Ed.D. Pensacola Christian College, M.S. Bowie State University, B.S. Elizabeth City State University and Certificates in School Administration, George Washington University, Trinity University - Washington and the University of the District of Columbia. E-mail: lordj_1@yahoo.com

\section{REFERENCES}

1. Aspin, David N. \& Chapman, Judith D. (2007) "Lifelong Learning Concepts and Conceptions" in: David N. Aspin, ed.: Philosophical Perspectives on Lifelong Learning, Springer

2. Bartholomew, S. K., \& Fusarelli, L. D. (2003). Reconnecting preparation and practice through the work lives of assistant principal. In F. C. Lunenburg \& C. S. Carr (Eds.), Shaping the future policy partnerships and emergin perspective (pp. 291-300). Lanham, Maryland: Scarecrow.

3. Bloom, G., \& Krovetz, M. (2001). A step into the principalship. Leadership, 30(3), 12-13 Retrieved from www.acsa.org/ publications/pub_detail.cfm?leadershipPubID=1031

4. Bolman, Lee G. and Terrence E. Deal. Reframing the Path to School Leadership: A Guide for Teachers and Principals. Thousand Oaks: Corwin Press, Inc., 2002

5. Celikten, M. (2000). The instructional leadership tasks of high school assistant principals. Journal of Educational Administration, 39 (1), 67-76. 
6. Darling-Hammond, L., M. LaPointe, D. Meyerson, M.T. Orr and C. Cohen (2007), Preparing School Leaders for a Changing World: Lessons from Exemplary Leadership Development Programs, Stanford University, Stanford

7. Elmore, R. F. (2000, Winter). Building a New Structure for School Leadership. Washington, DC: The Albert Shanker Institute

8. Ferlasso, L. (2009, August 26). Data-driven versus data-informed. Retrieved from http://larryferlazzo.edublogs.org/2009/08/26/data-driven-versus-data-informed

9. Fullan, M. (2005), Leadership and Sustainability, Thousand Oaks, CA: Corwin Press; Toronto: Ontario

10. Gentilucci, J.L., and Muto, C.C. (2007). Principals' Influence on Academic Achievement: The Student Perspective. NASS P Bulletin, 91(219), 219-236. Education and Urban Society, 18(1), 85-92

11. Hattie, J. (2012). Visible learning for teachers: Maximizing impact on learning. New York: Routledge

12. Lashway, L., (2002). Developing instructional leaders. Eugene, OR: University of Oregon, College of Education, ERIC Clearinghouse on Educational Management. (ERIC Document Reproduction Service No. ED 466023.

13. Little, J.W. (2003). "Professional Community and the Problem of High School Reform." International Journal of Educational Research 37(8): 693-714.

14. McBean, B., (2013). The Facts of Business Life. What successful business owner knows that you don't. John Wiley \& Sons, Hoboken, N.J.

15. National Association of Secondary School Principals. (2000). The principal shortage. Reston, VA: Author.

16. National Association of Secondary School Principals. (2009). The Assistant Principal of the Year. Reston, VA: Author

17. Sergiovanni, T. J., (1992). Building Community in Schools. Jossey Bass, San Francisco, CA. 